Irena Galińska-Rączy

\title{
Prawne uwarunkowania utworzenia żłobka i przedszkola dla dzieci parlamentarzystów oraz pracowników Kancelarii Sejmu (zgodnie z wnioskiem skierowanym do Marszałka Sejmu przez posła) ${ }^{1}$
}

\footnotetext{
Legal conditions regarding an establishment of a nursery and kindergarten for children of parliamentarians and employees of the Chancellery of the Sejm (in accordance with a request addressed to the Marshal of the Sejm by a Deputy): The law in force allows the Chancellery of the Sejm to establish a nursery. It could function as a company social facility within the meaning of the Act on the Company Social Benefits Fund. On the other hand, the author emphasizes that the Chancellery of the Sejm is not entitled to establish a kindergarten, because it cannot perceived as an entity which, according to the Act - the Education Law, is entitled to create and run such an institution. In addition, provisions being currently in force do not allow the creation of a facility that would contain both the nursery and the kindergarten.
}

Keywords: Chancellery of the Sejm, Deputies, education, child care, kindergarten, nursery, local government, capital city of Warsaw

Słowa kluczowe: Kancelaria Sejmu, posłowie, oświata, opieka nad dzieckiem, przedszkole, żłobek, samorząd terytorialny, m.st. Warszawa

Ekspert ds. legislacji BAS - irena.galinska-raczy@sejm.gov.pl • https://orcid.org/0000-0003-3586-0126

\section{Przedmiot opinii}

Przedmiotem niniejszej opinii jest udzielenie odpowiedzi na następujące pytania:

Opinia prawna w sprawie prawnych uwarunkowań utworzenia żłobka i przedszkola dla dzieci parlamentarzystów oraz pracowników Kancelarii Sejmu (zgodnie z wnioskiem skierowanym do Marszałka Sejmu przez Pania Poset XY) sporządzona 29 stycznia 2019 r. na zlecenie zastępcy Szefa Kancelarii Sejmu; BAS-WAP 12/19. 
- czy zasadny jest zgodnie z misją Kancelarii Sejmu projekt utworzenia żłobka i przedszkola dla dzieci parlamentarzystów i pracowników Kancelarii (uwzględniając finanse publiczne),

- czy w Polsce istnieją przedszkola/żłobki przyzakładowe w instytucjach publicznych,

- czy w parlamentach krajów członkowskich UE istnieją takie rozwiązania,

- czy m.st. Warszawa może prowadzić takie placówki dla posłów (podstawy formalno-prawne).

W opinii zostały wykorzystane m.in. następujące akty prawne:

- ustawa z 9 maja 1996 r. o wykonywaniu mandatu posła i senatora, t.j. Dz.U. 2018, poz. 1799; dalej: u.w.m.p.s.,

- uchwała Sejmu RP z 30 lipca 1992 r. - Regulamin Sejmu Rzeczypospolitej Polskiej, M.P. 2012, poz. 32, ze zm.,

- ustawa z 27 sierpnia 2009 r. o finansach publicznych, t.j. Dz.U. 2017, poz. 2077, ze zm.,

- ustawa z 15 marca 2002 r. o ustroju miasta stołecznego Warszawy, t.j. Dz.U. 2018, poz. 1817 ,

- ustawa z 8 marca 1990 r. o samorządzie gminnym, t.j. Dz.U. 2018, poz. 994, ze zm.,

- ustawa z 20 grudnia 1996 r. o gospodarce komunalnej, t.j. Dz.U. 2017, poz. 827, ze zm.,

- ustawa z 4 marca 1994 r. o zakładowym funduszu świadczeń socjalnych, t.j. Dz.U. 2018, poz. 1316, ze zm.; dalej: u.z.f.ś.s.,

- ustawa z 14 grudnia 2016 r. - Prawo oświatowe, t.j. Dz.U. 2018, poz. 966, ze zm.,

- ustawa z 4 lutego 2011 r. o opiece nad dziećmi w wieku do lat 3, t.j. Dz.U. 2018, poz. 603, ze zm.; dalej: ustawa żłobkowa.

\section{Zadania Kancelarii Sejmu a możliwość utworzenia oddziału żłobkowo-przedszkolnego dla dzieci posłów oraz dzieci pracowników Kancelarii}

1. Odnosząc się do pytania o zasadność projektu przedstawionego we wstępie opinii z punktu widzenia misji Kancelarii Sejmu i finansów publicznych, należy podkreślić, że sama idea utworzenia tego typu placówki nie jest sprzeczna z kompetencjami Kancelarii Sejmu jako pracodawcy, któremu obowiązujące przepisy przyznają prawo tworzenia i prowadzenia przyzakładowego żłobka (ale nie przedszkola, o czym będzie w dalszej części opinii).

Idea taka nie pozostaje również $\mathrm{w}$ sprzeczności $\mathrm{z}$ szeroko pojmowaną rolą i zadaniami Kancelarii Sejmu, którymi są zgodnie z art. 46 ust. 2 u.w.m.p.s.: $z a-$ 
pewnienie i organizacja obsługi posłów niezbędnej do wykonywania przez nich obowiązków oraz zgodnie z art. 199 ust. 2 regulaminu Sejmu RP stwarzanie posłom warunków do wykonywania mandatu, w tym stwarzanie warunków „uczestniczenia w pracach Sejmu i jego organów”. W doktrynie podkreśla się, że: pojmowanie tej obsługi musi być rozumiane nieco szerzej i obejmować również pomoc $w$ realizacji przysługujących im praw, a nie wyłącznie obowiązków poselskich ${ }^{2}$, co wynika m.in. z art. 3 u.w.m.p.s. ${ }^{3}$. Do takich praw można zaliczać np. uprawnienia socjalne przysługujące parlamentarzystom.

Utworzenie wnioskowanej placówki dla dzieci posłów wpisywałoby się z jednej strony w pomoc Kancelarii Sejmu w wykonanie zadania polegającego na umożliwieniu czynnego uczestnictwa w pracach Sejmu, jego organów i pracach Zgromadzenia Narodowego ${ }^{4}$, zaś z drugiej mogłoby stanowić realizację uprawnień socjalnych z zakładowego funduszu świadczeń socjalnych, który tworzony jest dla posłów na podstawie art. 41 u.w.m.p.s. ${ }^{5}$.

W omawianym zakresie przywołać można również art. 4 u.w.m.p.s., stanowiący ogólną dyrektywę m.in. w zakresie interpretacji art. 41 i 46 tego aktu, zgodnie z którą posłom: zapewnia się warunki niezbędne do skutecznej realizacji ich obowiązków oraz ochronę praw wynikających ze sprawowania mandatu.

2. Tak jak w przypadku innych świadczeń przysługujących posłom, realizacja omawianego projektu odbywałaby się zgodnie z art. 47 u.w.m.p.s. ${ }^{6}$ ze środków budżetu państwa (zgodnie $\mathrm{z}$ zasadami przewidzianymi w ustawie o finansach publicznych) oraz częściowo ze środków zakładowego funduszu świadczeń socjalnych utworzonego dla posłów oraz pracowników Kancelarii Sejmu.

2 P. Uziębło [w:] K. Grajewski, J. Stelina, P. Uziębło, Komentarz do ustawy o wykonywaniu mandatu posta i senatora, Warszawa 2014, s. 495.

3 Art. 3 stanowi: Podstawowym prawem $i$ obowiąkiem posła i senatora jest czynne uczestnictwo w pracach Sejmu lub Senatu oraz Zgromadzenia Narodowego, a także ich organów.

4 W $\$ 1$ ust. 2 statutu Kancelarii Sejmu (załącznik do zarządzenia nr 6 Marszałka Sejmu z 21 marca 2002 r., ze zm.) postanowiono: Kancelaria Sejmu stwarza posłom warunki do uczestniczenia $w$ pracach Sejmu i jego organów.

5 Art. 41. 1. Posłowie i senatorowie oraz członkowie ich rodzin sq uprawnieni do korzystania z funduszu świadczeń socjalnych, utworzonego na zasadach określonych w przepisach o zakładowym funduszu świadczeń socjalnych.

2. Byli posłowie i senatorowie oraz członkowie ich rodzin korzystaja z funduszu świadczeń socjalnych na zasadach określonych w przepisach o zakładowym funduszu świadczeń socjalnych.

3. Zasady przeznaczania środków z funduszu, o którym mowa w ust. 1, na poszczególne cele i rodzaje działalności socjalnej oraz zasady i warunki korzystania $z$ usług i świadczeń finansowanych $z$ tego funduszu określają odpowiednio Marszałek Sejmu i Marszałek Senatu.

$6 \quad$ Art. 47. Wydatki wynikające z uprawnień posłów i senatorów pokrywa się z budżetu państwa, w części dotyczącej odpowiednio Kancelarii Sejmu lub Kancelarii Senatu. 


\section{Prawne możliwości utworzenia przez Kancelarię Sejmu żłobka i przedszkola dla dzieci parlamentarzystów oraz pracowników tej instytucji}

1. Wniosek skierowany do Marszałka Sejmu dotyczy zorganizowania oddziału żłobkowo-przedszkolnego (dla dzieci w wieku od 0,5 roku do 4 lat) na terenie będącym w zarządzie Kancelarii Sejmu dla pracowników Kancelarii oraz parlamentarzystów. We wniosku postuluje się stworzenie przez Kancelarię Sejmu placówki przyzakładowej, której funkcjonowanie byłoby warunkowane charakterem pracy (czyli m.in. posiedzeniami Sejmu i Senatu, które trwają do późnych godzin wieczornych) i aktualnymi potrzebami pracowników i posłów. Opłaty za korzystanie z tej formy opieki nad dziećmi powinny być pobierane jak w placówkach publicznych.

2. Przedmiotowy wniosek odnosi się do dwóch różnych form opieki nad dziećmi i wychowania (żłobka i przedszkola), co wynika z obecnego systemu oświaty ukształtowanego ustawą - Prawo oświatowe oraz ustawą o opiece nad dziećmi w wieku do lat 3. Obowiązujące przepisy nie przewidują możliwości tworzenia placówki, która łączyłaby te dwie formy ${ }^{7}$. Powołana ustawa żłobkowa przewiduje jedynie możliwość tworzenia żłobka w budynku, w którym znajduje się przedszkole ${ }^{8}$.

Zgodnie z art. 31 ust. 1 Prawa oświatowego: Wychowanie przedszkolne obejmuje dzieci od początku roku szkolnego w roku kalendarzowym, w którym dziecko kończy 3 lata, do końca roku szkolnego $w$ roku kalendarzowym, $w$ którym dziecko kończy 7 lat. Wychowanie przedszkolne jest realizowane $w$ przedszkolach, oddziałach przedszkolnych $w$ szkołach podstawowych oraz $w$ innych formach wychowania przedszkolnego 9 .

Do opieki nad dziećmi młodszymi odnoszą się regulacje zawarte w ustawie o opiece nad dziećmi w wieku do lat 3. W myśl art. 2 ust. 1 tej ustawy opieka nad dziećmi w wieku do lat 3 może być organizowana w formie żłobka (klubu

$7 \quad$ Przykładem przepisu, który umożliwia powstanie zespołu jest art 9 ust. 1 ustawy z 4 lutego 2011 r. o opiece nad dziećmi w wieku do lat 3, który stanowi, że podmioty prowadzące żłobki lub kluby dziecięce mogą dla celów organizacyjnych połączyć je w zespół i określić zasady działania zespołu, przy czym połączenie to nie narusza odrębności żłobków lub klubów dziecięcych w zakresie wpisu do rejestru.

8 Art. 9b. Formy opieki nad dziećmi w wieku do lat 3 moga mieścić się w jednym budynku $z$ przedszkolami $w$ rozumieniu ustawy z dnia 14 grudnia 2016 r. - Prawo oświatowe, także w przypadku, gdy znajduja się w jednej strefie pożarowej, bez względu na kategorię zagrożenia ludzi, do której jest zaliczona dana strefa pożarowa.

9 W art. 31 ust. 3 Prawa oświatowego uczyniono następujący wyjątek: W szczególnie uzasadnionych przypadkach wychowaniem przedszkolnym może także zostać objęte dziecko, które ukończyło 2,5 roku. 
dziecięcego lub sprawowana przez dziennego opiekuna oraz nianię) $)^{10}$. Zgodnie $\mathrm{z}$ art. 7 ust. 1 opieka w żłobku jest sprawowana nad dziećmi w wieku od ukończenia 20 tygodnia życia.

3. Rozważając możliwość utworzenia przez Kancelarię Sejmu żłobka i przedszkola, należy ustalić, czy instytucja ta może być podmiotem tworzącym i prowadzącym tego typu placówki.

Zgodnie z art. 8 ust. 1 ustawy żłobkowej: Żłobki i kluby dziecięce mogą tworzyć i prowadzić:

1) jednostki samorzadu terytorialnego oraz instytucje publiczne;

2) osoby fizyczne;

3) osoby prawne i jednostki organizacyjne nieposiadajace osobowości prawnej.

W inny sposób podmioty mogące tworzyć przedszkola określa Prawo oświatowe. Artykuł 8 ust. 1 (w związku z art. 4 pkt 1) tej ustawy wskazuje, że przedszkole może założyć i prowadzić:

1) jednostka samorządu terytorialnego,

2) inna osoba prawna,

3) osoba fizyczna.

Z zestawienia powołanych przepisów wynika, że Kancelaria Sejmu nie może być podmiotem, który tworzy i prowadzi przedszkole. Instytucja ta może natomiast utworzyć żłobek. Możliwość taka powstała po nowelizacji art. 8 ustawy żłobkowej, która obowiązuje od 1 stycznia 2018 r., a została dokonana ustawą z 7 lipca 2017 r. o zmianie niektórych ustaw związanych z systemami wsparcia rodzin (Dz.U. poz. 1428).

Do Kancelarii Sejmu jako „instytucji publicznej” w rozumieniu art. 8 ust. 1 pkt 1 ustawy żłobkowej ${ }^{11}$ odnoszą się również ust. 2a-2c tego artykułu w brzmieniu:

2a. Instytucje publiczne tworza i prowadza żłobki i kluby dziecięce dla dzieci pracowników zatrudnionych $w$ tych instytucjach.

10 Z wyjątkiem przewidzianym w art. 2 ust. 3 tego aktu: Opieka nad dzieckiem może być sprawowana do ukończenia roku szkolnego, $w$ którym dziecko ukończy 3 rok życia lub $w$ przypadku gdy niemożliwe lub utrudnione jest objęcie dziecka wychowaniem przedszkolnym - 4 rok życia.

11 Na stronie internetowej Ministerstwa Rodziny, Pracy i Polityki Społecznej pod adresem https://www.gov.pl/web/rodzina/lobek-i-klub-dzieciecy [dostęp 23 stycznia 2019 r.] zamieszczono następującą informację: Podmioty mogace tworzyć i prowadzić żłobki i kluby dziecięce:

1) jednostki samorządu terytorialnego (gminy, powiaty, województwa)

2) instytucje publiczne (na przykład urzad, sąd, trybunat, NFZ, PAN)

3) osoby fizyczne

4) osoby prawne

5) jednostki organizacyjne nieposiadające osobowości prawnej. 
2b. Do żłobka lub klubu dziecięcego prowadzonych przez instytucje publiczne moga być przyjmowane dzieci inne niż dzieci pracowników zatrudnionych $w$ tych instytucjach, jeżeli w żłobku lub klubie dziecięcym sa wolne miejsca.

2c. Żłobek lub klub dziecięcy moga być prowadzone łacznie przez więcej niż jedna instytucję publiczną.

Z powyższego wynika m.in., że żłobek mógłby być prowadzony wspólnie np. z Kancelarią Senatu. Nie można przy tym wykluczyć powierzenia prowadzenia takiej placówki przez wyspecjalizowaną w tym zakresie firmę (co zaleca Ministerstwo Rodziny, Pracy i Polityki Społecznej w materiale zamieszczonym na stronie internetowej ${ }^{12}$ ).

4. Dodatkowymi pozytywnymi uwarunkowaniami prawnymi dla rozważanego projektu są przepisy ustawy z 4 marca 1994 r. o zakładowym funduszu świadczeń socjalnych. Ustawa ta zgodnie $\mathrm{z}$ art. 1 ust. 1 określa zasady tworzenia przez pracodawców zakładowego funduszu świadczeń socjalnych, zwanego dalej „Funduszem”, i zasady gospodarowania środkami tego Funduszu, przeznaczonego na finansowanie działalności socjalnej organizowanej na rzecz osób uprawnionych do korzystania z Funduszu, na dofinansowanie zakładowych obiektów socjalnych oraz na tworzenie zakładowych żłobków, klubów dziecięcych, przedszkoli oraz innych form wychowania przedszkolnego. Zgodne z art. 2 pkt 1 powołanej ustawy przez określenie „działalność socjalna” należy rozumieć m.in.: ustugi świadczone przez pracodawców na rzecz [...] opieki nad dziećmi $w$ żłobkach, klubach dziecięcych, sprawowanej przez dziennego opiekuna lub nianię, $w$ przedszkolach oraz innych formach wychowania przedszkolnego, udzielanie pomocy materialnej - rzeczowej lub finansowej, [...].

Żłobki mogą być tworzone przez podmioty będące pracodawcami (tak jak Kancelaria Sejmu), w szczególności zaś te, u których stosownie do art. 3 u.z.f.ś.s. tworzy się zakładowy fundusz świadczeń socjalnych - u takich pracodawców żłobki mają charakter zakładowych obiektów socjalnych, a ustawodawca wprowadził rozwiązania ułatwiające pracodawcom podejmowanie działalności socjalnej polegającej na tworzeniu i prowadzeniu tych form opieki nad dziećmi $\mathrm{w}$ wieku do lat 3 .

Z zakładowego funduszu świadczeń socjalnych mogą być zaś dofinansowane zakładowe obiekty socjalne, a więc zgodnie z przepisem art. 2 pkt 4 u.z.f.ś.s. m.in. żłobki, kluby dziecięce i przedszkola ${ }^{13}$.

12 Rodzinaipraca.gov.pl/narzędzia-godzenia-rol/zlobek-klub-dzieciecy-przedszkole-zakladowe.

13 Art. 2. Użyte w ustawie określenia oznaczają: [...]

4) zakładowe obiekty socjalne - ośrodki wczasowe i kolonijne, domy wypoczynkowe, sanatoria, ogrody działkowe, obiekty sportowo-rekreacyjne, żłobki, kluby dziecięce i przedszkola oraz obiekty stużące działalności kulturalnej; [...] 
W komentarzu do omawianej ustawy podkreśla się, że dofinansowanie nie oznacza finansowania, czyli ponoszenia pełnych kosztów ich utrzymania, które obciążają pracodawcę; przez dofinansowanie należy rozumieć przekazanie środków na zmniejszenie wydatków związanych np. z utrzymaniem obiektów lub na sfinansowanie konkretnych zakupów ${ }^{14}$. Uznaje się, że: [...] środki funduszu moga być zainwestowane $w$ utworzenie zakładowej placówki opieki nad dziećmi, a zatem można je przeznaczyć na wynajem lub dzierżawę budynku na ten cel badź budowę nowego obiektu przeznaczonego na ten cel. Jednakże wydatki związane z funkcjonowaniem tych placówek po ich utworzeniu, takie jak opłaty za energie elektryczna, gaz, wynagrodzenia i składki na ubezpieczenie społeczne pracowników zatrudnionych $w$ powstałych placówkach, będa mogły być finansowane nie z zakładowego funduszu świadczeń socjalnych, lecz przez pracodawcę i będa wchodzić w koszty jego działalności. Z obowiązujących przepisów podatkowych wynika, że wydatki ponoszone przez pracodawce na utrzymanie zakładowych obiektów socjalnych $w$ części niepokrytej ze środków zakładowego funduszu świadczeń socjalnych uznaje się za koszty uzyskania przychodu pracodawcy. Dofinansowanie z funduszu socjalnego obiektu socjalnego takiego jak żłobek, przedszkole itd. może sprowadzić się jedynie do udzielenia dotacji socjalnej, która będzie miała na celu podniesienie standardu usług świadczonych przez taka placówkę (zakup książek, zabawek, nowych mebli). Dofinansowując placówkę opiekuńcza z zakładowego funduszu socjalnego, pracodawca może obniżyć wysokość opłat, które ponosza pracownicy korzystajacy z jej usług ${ }^{15}$.

$\mathrm{W}$ omawianej ustawie przewidziano również uprawnienie do zwiększenia odpisu na zakładowy fundusz o 7,5\% podstawy ustalania odpisu ${ }^{16}$.

Dla analizowanych zagadnień (zwłaszcza aspektu kryterium dochodowego, które mogłoby mieć znaczenie w przypadku tworzenia placówki dla parlamentarzystów) istotne wydaje się stanowisko zaprezentowane w wyroku Sądu Apelacyjnego w Poznaniu ${ }^{17}$.

14 A. Martuszewicz, K. Piecyk, Ustawa o zakładowym funduszu świadczeń socjalnych. Komentarz, 2011, LEX.

15 K. Piecyk [w:] ibidem. Podobne stanowisko prezentuje T. Niedziński, Zakładowy Fundusz Świadczeń Socjalnych. Komentarz, 2011, Legalis, komentarz do art. 1.

16 Art. 5 ust. 5a. Pracodawcy, którzy utworzyli zakładowy żłobek lub klub dziecięcy oraz przeznacza na ten cel z odpisu podstawowego kwote odpowiadająca 7,5 punktu procentowego tego odpisu moga zwiększyć Fundusz na każdą zatrudniona osobę o 7,5\% przeciętnego wynagrodzenia miesięcznego, o którym mowa w ust. 2, pod warunkiem przeznaczenia całości tego zwiększenia na prowadzenie żłobka lub klubu dziecięcego.

17 Wyrok Sądu Apelacyjnego w Poznaniu z 14 marca 2013 r. w sprawie o sygn. akt III AUa 1293/12, LEX nr 1313407. W opinii tego Sądu: Ustawa $z 1994$ r. o zakładowym funduszu świadczeń socjalnych określając zasady jego tworzenia nie wspomina o obowiązku stosowania kryteriów socjalnych, a dopuszcza możliwość dofinansowania zakładowych obiektów socjalnych oraz powstania i organizowania żłobków i przedszkoli 


\section{Przykłady placówek przedszkolnych i żłobków prowadzonych przez instytucje publiczne}

Z dotychczasowych ustaleń wynika, że Kancelaria Sejmu może utworzyć tylko żłobek. Nie może utworzyć przedszkola ani placówki, która byłaby połączeniem żłobka jako instytucjonalnej formy opieki nad najmłodszymi dziećmi (od ukończenia 20 tygodnia życia do ukończenia 3. roku życia) z wychowaniem przedszkolnym prowadzonym w przedszkolu (jako placówce pozostającej w systemie oświaty).

W związku z tym nieistotne wydają się informacje na temat przedszkoli prowadzonych np. przez uczelnie publiczne (wśród tych podmiotów wskazać można: Przedszkole Uniwersytetu Łódzkiego, Elastyczne Przedszkole przy Wyższej Szkole Ekonomicznej w Białymstoku „Orzełek”). Ze względu na szczególne przepisy, na podstawie których powstawały żłobki i kluby dziecięce na uczelniach publicznych (jako szczególna kategoria zakładowych żłobków ${ }^{18}$ ) nieprzydatne mogą okazać się również informacje na temat takich placówek, jak np. żłobek

$z$ zasobów funduszu, nie wiążąc tego z kryteriami socjalnymi. Kryteria socjalne udzielenia pomocy obowiąujace $w$ stosunku do konkretnego pracownika w tym przypadku nie sa brane w ogóle pod uwagę. Ustawa, nie warunkuje, aby wydatki funduszu zawsze ukierunkowane były na konkretnego odbiorcę. Z analizy tych przepisów wynika, że ustawodawca obok świadczeń ulgowych przewiduje również inne świadczenia, a ponadto zobowiązuje pracodawcę do określenia zasad i warunków korzystania ze środków funduszu w zakładowym regulaminie działalności socjalnej. Regulamin funduszu może ograniczać sie jedynie do przyznania ulgowych świadczeń $z$ funduszu z zastosowaniem kryteriów socjalnych, ale może też wymienić inne sposoby wydatkowania środków w ramach działalności socjalnej.

18 Powstawały one na podstawie uchylonej ustawy z 27 lipca 2005 r. - Prawo o szkolnictwie wyższym (Dz.U. 2016, poz. 1842, ze zm.): Art. 157. 1. Dla pracowników uczelni publicznych tworzy się odpis na zakładowy fundusz świadczeń socjalnych w wysokości 6,5\% planowanych przez uczelnię rocznych wynagrodzeń osobowych.

2. W uczelniach publicznych moga być tworzone pracownicze programy emerytalne wykorzystujące zakładowy fundusz świadczeń socjalnych do wysokości 30\%.

3. Odpis na zakładowy fundusz świadczeń socjalnych na jednego byłego pracownika uczelni publicznej będącego emerytem lub rencista wynosi za dany rok kalendarzowy $10 \%$ rocznej sumy najniższej emerytury lub renty $z$ roku poprzedniego, ustalonej zgodnie $z$ art. 94 ust. 2 pkt 1 lit. a ustawy $z$ dnia 17 grudnia 1998 r. o emeryturach i rentach z Funduszu Ubezpieczeń Społecznych (Dz. U. z 2016 r. poz. 887).

4. Odpisy, o których mowa w ust. 1 i 3, stanowiq w uczelni publicznej jeden fundusz.

4a. Z zakładowych żłobków i klubów dziecięcych moga korzystać dzieci studentów i uczestników studiów doktoranckich.

4b. Opłaty, o których mowa w art. 58 ust. 2 ustawy $z$ dnia 4 lutego 2011 r. o opiece nad dziećmi w wieku do lat 3 (Dz. U. z 2016 r. poz. 157), zwiększaja zakładowy fundusz świadczeń socjalnych. 
dla pracowników Uniwersytetu Śląskiego w Katowicach czy Uniwersytetu Warszawskiego (funkcjonujący w Warszawie pod nazwą „Uniwersyteckie Maluchy”).

Dla omawianej inicjatywy istotna wydaje się wstępna informacja uzyskana w Departamencie Polityki Rodzinnej w Ministerstwie Rodziny, Pracy i Polityki Społecznej wynikająca ze sprawozdawczości prowadzonej przez to Ministerstwo w zakresie realizacji opieki nad dziećmi w wieku do lat 3 na podstawie art. 64 i 65a ustawy żłobkowej ${ }^{19}$ (pełna informacja będzie opracowana przez Ministerstwo po uzyskaniu wszystkich sprawozdań - zob. art. 64 ust. 6 oraz 64a ust. 2

5. W sprawach nieuregulowanych $w$ ust. 1, 3 i 4 stosuje się przepisy o zakładowym funduszu świadczeń socjalnych.

19 Art. 64. 1. Podmioty prowadzące żłobki lub kluby dziecięce, podmioty zatrudniające dziennego opiekuna oraz osoby, o których mowa w art. 36 ust. 1 pkt 1, sa zobowiązane do sporzadzania sprawozdań z zakresu opieki nad dziećmi w wieku do lat 3.

2. Sprawozdania, o których mowa w ust. $1, z$ zakresu opieki nad dziećmi w wieku do lat 3:

1) organizowanej przez gmine - gmina przekazuje wojewodzie,

2) organizowanej przez podmioty inne niż gmina - podmioty te przekazuja gminie, a gmina przekazuje zbiorcze sprawozdanie wojewodzie - w postaci elektronicznej, za pomoca systemu teleinformatycznego, o którym mowa wart. $62 a$.

3. Wojewoda sporzadza zbiorcze sprawozdanie z zakresu opieki nad dziećmi w wieku do lat 3 i przekazuje je, w postaci elektronicznej, za pomoca systemu teleinformatycznego, o którym mowa w art. 62a, ministrowi właściwemu do spraw rodziny.

4. W sprawozdaniach, o których mowa w ust. 1, przekazywane sq następujące dane:

1) liczba osób zatrudnionych $w$ żłobku lub klubie dziecięcym według stanowiska pracy;

2) informacja o niezaspokojonym zapotrzebowaniu na miejsca opieki w żłobku, klubie dziecięcym lub u dziennego opiekuna;

3) informacja o połączeniu żłobków lub klubów dziecięcych $w$ zespoły ze wskazaniem poszczególnych form opieki nad dziećmi w wieku do lat 3 i ich liczby;

4) informacja o zorganizowaniu wspólnej obsługi administracyjnej, finansowej i organizacyjnej żłobków, klubów dziecięcych lub ich zespołów, w tym informacja o wykonywaniu tej obstugi przez jednostki, o których mowa w art. 10 ust. 2 ustawy $z$ dnia 14 grudnia 2016 r. - Prawo oświatowe;

5) wysokość otrzymywanych dotacji ze środków publicznych, w tym ze środków Unii Europejskiej, na jedno dziecko;

6) wysokość wydatków ponoszonych przez jednostki samorządu terytorialnego i instytucje publiczne.

5. Podmioty inne niż gmina prowadzace żłobki lub kluby dziecięce, zatrudniające dziennego opiekuna oraz osoby, o których mowa $w$ art. 36 ust. 1 pkt 1, przekazuja właściwej gminie sprawozdania za okres od dnia 1 stycznia do dnia 31 grudnia - w terminie do dnia 31 stycznia roku następnego. Gmina przekazuje wojewodzie sprawozdania $z$ zakresu sprawowanej przez siebie opieki nad dziećmi w wieku do lat 3 za okres od dnia 1 stycznia do dnia 31 grudnia oraz zbiorcze sprawozdania z zakresu opieki nad dziećmi $w$ wieku do lat 3 organizowanej przez podmioty inne niż gmina $-w$ terminie do dnia 14 lutego każdego roku. 
ustawy żłobkowej). Według danych zgromadzonych do tej pory przez Ministerstwo Rodziny, Pracy i Polityki Społecznej wśród podmiotów prowadzących żłobki i kluby dziecięce nie ma instytucji publicznych (z informacji uzyskanych w Ministerstwie wynika, że w resorcie tym rozważano utworzenie żłobka, który byłby prowadzony wspólnie z Ministerstwem Gospodarki).

\section{Funkcjonowanie placówek przedszkolnych w parlamentach krajów UE}

Według opracowania przygotowanego przez Biuro Analiz Sejmowych - Świadczenia poselskie $w$ różnych krajach ${ }^{20}$ - jedynym krajem, w którym przewidziano możliwość korzystania przez parlamentarzystów z opieki nad dziećmi w przedszkolu, jest Norwegia. W publikacji tej zawarto następującą informację: Storting ma umowę z prywatnym przedszkolem zapewniającym miejsce dla maksimum 15 dzieci parlamentarzystów, zgodnie z wytycznymi przyjętymi przez prezydium. Rodzice płaca 2250 koron miesięcznie. Nabór jest regulowany poprzez wytyczne określone przez prezydium Stortingu ${ }^{21}$.

\section{Możliwość utworzenia i prowadzenia niepublicznego przedszkola oraz żłobka przez samorząd m.st. Warszawy}

1. W myśl art. 1 ust. 1 ustawy z 15 marca 2002 r. o ustroju miasta stołecznego Warszawy Warszawa jest gminą mającą status miasta na prawach powiatu. Zgodnie $z$ art. 92 ust. 2 ustawy o samorządzie powiatowym miasto na prawach powiatu jest gminą wykonującą zadania powiatu, w której funkcję organów powiatu sprawują rada miasta i prezydent miasta (art. 92 ust. 1 tej ustawy), a ich ustrój i działanie oraz zasady sprawowania nadzoru nad nimi określa ustawa o samorządzie gminnym (art. 92 ust. 3 tej ustawy). Miasta na prawach powiatu są przede wszystkim gminami, które różnią się od innych gmin tym, że wykonują dodatkowo zadania powiatu, a - oprócz przepisów dotyczących samorządu gminnego

6. Wojewoda przekazuje ministrowi właściwemu do spraw rodziny zbiorcze sprawozdanie w terminie do dnia 28 lutego każdego roku.

Art. 64a. 1. Gmina jest zobowiązana do przekazywania podlegajacych ujawnieniu danych $z$ rejestru oraz $z$ wykazu wojewodzie i ministrowi właściwemu do spraw rodziny za pośrednictwem systemu teleinformatycznego, o którym mowa wart. $62 a$.

2. Minister właściwy do spraw rodziny publikuje dane, o których mowa w ust. 1, na stronach internetowych ministerstwa.

20 „Studia BAS” 2007 [Świadczenia poselskie w różnych krajach, red. Z. Szpringer].

${ }_{21}$ Z. Szpringer, Informacja na temat finansowania działalności poselskiej w Norwegii, „Studia BAS” 2007, op. cit., s. 55. 
- stosuje się do nich niektóre regulacje dotyczące powiatów (w zakresie, w jakim miasta te wykonują zadania przypisane powiatom) ${ }^{22}$.

Zgodnie z art. 8 ust. 15 Prawa oświatowego zakładanie i prowadzenie publicznych przedszkoli ( $w$ tym z oddziałami integracyjnymi lub specjalnymi, przedszkoli integracyjnych i specjalnych oraz innych form wychowania przedszkolnego, o których mowa w art. 32 ust. 2 tej ustawy) należy do zadań własnych gmin ${ }^{23}$. Przedszkolem publicznym jest przedszkole, które spełnia kryteria wskazane w art. 13 ust. 1 tej ustawy, czyli m.in.: przeprowadza rekrutację dzieci zgodnie z zasadą powszechnej dostępności (art. 13 ust. 1 pkt 3).

$\mathrm{Z}$ analizowanych przepisów wynika, że m.st. Warszawa może zakładać i prowadzić przedszkola, które są placówkami publicznymi. Utworzenie przez tę jednostkę samorządu terytorialnego placówki, która miałaby charakter niepubliczny (przeznaczonej wyłącznie dla dzieci parlamentarzystów i pracowników Kancelarii Sejmu oraz Senatu) nie jest zatem możliwe.

2. Inaczej kwestię funkcjonowania publicznych i niepublicznych placówek uregulowano w ustawie żłobkowej. Z aktu tego wynika, że ustawodawca nie zróżnicował prawnie statusu żłobka publicznego i niepublicznego. Nie rozróżniono również statusu żłobków powierzanych do prowadzenia przez gminy podmiotom prywatnym w drodze umowy (zob. art. 61), ponieważ wymogi dotyczące zakładania i prowadzenia żłobków zostały ustalone w sposób jednolity.

Zgodnie z art. 8 ust. 2 ustawy z 17 maja 1990 r. o podziale zadań i kompetencji określonych w ustawach szczególnych pomiędzy organy gminy a organy administracji rządowej oraz o zmianie niektórych ustaw (Dz.U. nr 34, poz. 198, ze zm.) zakładanie i utrzymanie żłobków należy do zadań własnych gminy.

Artykuł 8 ust. 2 ustawy żłobkowej określa formę organizacyjno-prawną, w której gminy mogą tworzyć i prowadzić żłobki i kluby dziecięce, wskazując, że jest to gminna jednostka budżetowa. W komentarzu do tego przepisu stwierdzono: Oznacza to, że - stosownie do art. 11 ust. 1 u.f.p. - żłobki i kluby dziecięce prowadzone przez gmine sa jednostkami organizacyjnymi nieposiadajacymi osobowości prawnej, które pokrywaja swoje wydatki bezpośrednio z budżetu gminy, a pobrane dochody odprowadzaja na jego rachunek. Przyjęcie dla żłobków i klubów dziecięcych prowadzonych przez gmine formy jednostki budżetowej ma wiele istotnych konsekwencji, wynikajacych ze stosowania do nich przepisów ustawy o finansach publicznych. Najważniejsze z nich to: a) gminne żłobki i kluby dziecięce sa tworzone, łaczone i likwidowane $w$ drodze uchwały przez rade gminy (art. 12

22 Zob. A. Wierzbica, Miasto na prawach powiatu. Zagadnienia ustrojowe, Warszawa 2006.

23 Zgodnie $\mathrm{z}$ art. 32 ust. 1 Prawa oświatowego rada gminy ustala sieć prowadzonych przez gminę publicznych przedszkoli i oddziałów przedszkolnych w szkołach podstawowych. Uchwała rady gminy podlega ogłoszeniu w wojewódzkim dzienniku urzędowym. 
ust. 2 u.f.p.), która jednocześnie nadaje im statut (art. 12 ust. 2 u.f.p.) i przekazuje mienie $w$ zarzad; b) gminne żłobki i kluby dziecięce prowadza gospodarke finansowa w oparciu o plany finansowe, których projekty przygotowuja ich dyrektorzy (osoby kierujące ich praca) (art. 11 ust. 3 u.f.p.); c) gminne żłobki i kluby dziecięce nie maja statusu przedsiębiorcy, ponieważ stosownie do art. 4 ust. 1 u.s.d.g. [ustawa z 2 lipca 2004 r. o swobodzie działalności gospodarczej - dopisek I.G.-R.] do uznania danego podmiotu za przedsiębiorce niezbędne jest, by wykonywał działalność gospodarcza we własnym imieniu; gminne jednostki budżetowe zaś, nawet jeśli taką działalność podejmują, to korzystaja w tym zakresie z osobowości prawnej gminy i wykonuja ja w jej imieniu ${ }^{24}$.

Zważywszy na możliwość utworzenia żłobka zarówno przez jednostki samorządu terytorialnego (czyli np. gminę, w tym m.st. Warszawę), jak i instytucje publiczne (np. Kancelarię Sejmu), o czym w sposób wyraźny mówi art. 8 ust. 1 pkt 1 ustawy żłobkowej (Żłobki i kluby dziecięce moga tworzyć i prowadzić: 1) jednostki samorzadu terytorialnego oraz instytucje publiczne; [...]), można mieć wątpliwości (zwłaszcza z punktu widzenia ratio legis tego przepisu), czy instytucja publiczna (która sama może założyć i prowadzić przyzakładowy żłobek) może zlecać jednostce samorządu prowadzenie żłobka, który byłby przeznaczony wyłącznie dla dzieci pracowników tej instytucji.

Wątpliwość powyższą potęguje fakt, że z omawianych przepisów wynika, iż zakładanie i utrzymanie żłobków należy do zadań własnych gminy, co oznacza, że chodzi o zaspokajanie zbiorowych potrzeb wspólnoty gminnej (samorządowej), o których mowa w art. 7 ust. 1 zdanie pierwsze ustawy o samorządzie gminnym ${ }^{25}$ oraz art. 1 ust. 1 ustawy o gospodarce komunalnej ${ }^{26}$ (w związku z art. 5 tej ustawy $\left.{ }^{27}\right)$. Innymi słowy, chodzi o zadania, które powinny co do zasady służyć zaspokajaniu potrzeb danej wspólnoty samorządowej (tj. wspólnoty gminnej) ${ }^{28}$ i odbywać się „w drodze świadczenia usług powszechnie dostępnych”29. Zawęża-

24 S. Gajewski [w:] S. Gajewski, A. Jakubowski, Ustawa o opiece nad dziećmi w wieku do lat 3. Komentarz, 2014, LEX.

25 Zaspokajanie zbiorowych potrzeb wspólnoty należy do zadań własnych gminy.

26 Ustawa określa zasady i formy gospodarki komunalnej jednostek samorzadu terytorialnego, polegające na wykonywaniu przez te jednostki zadań własnych, w celu zaspokojenia zbiorowych potrzeb wspólnoty samorzadowej.

27 Przepisy ustawy stosuje się odpowiednio do wykonywania zadań, o których mowa $w$ art. 1, przez związki międzygminne, związki powiatów, związki powiatowo-gminne (związki komunalne), przez związki metropolitalne, przez miasto stołeczne Warszawe oraz $w$ ramach porozumień komunalnych.

28 W tej mierze przywołać można również art. 166 ust. 1 Konstytucji: Zadania publiczne służące zaspokajaniu potrzeb wspólnoty samorządowej sq wykonywane przez jednostkę samorzadu terytorialnego jako zadania własne.

29 Porównaj z art. 1 ust. 2 ustawy o gospodarce komunalnej: Gospodarka komunalna obejmuje w szczególności zadania o charakterze użyteczności publicznej, których celem 
nie kręgu osób, które mogłyby korzystać ze żłobka do pracowników jednej instytucji (czy nawet dwóch, takich jak np. Kancelarie Sejmu i Senatu) czy do określonych osób (np. parlamentarzystów), pozostawałoby w sprzeczności z tymi zadaniami i zasadami.

Powyższe wątpliwości odnoszą się również do możliwości utworzenia żłobka na podstawie art. 61 ust. 1 ustawy żłobkowej, zgodnie z którym wójt, burmistrz lub prezydent miasta może zlecić podmiotom, o których mowa w art. 8 ust. 1 tej ustawy, czyli m.in. podmiotom prywatnym, organizację opieki sprawowanej m.in. w formie żłobka ${ }^{30}$. Konstrukcja przewidziana komentowanym przepisem jest przejawem prywatyzacji wykonywania zadań publicznych. Samo zadanie, które jest przedmiotem zlecenia, zachowuje bowiem publiczny charakter, ale istnieje możliwość, by było bezpośrednio wykonywane przez podmiot niepubliczny ${ }^{31}$. Wydaje się, że również w przypadku, kiedy gmina zleci innemu podmiotowi prowadzenie (zorganizowanie) żłobka, placówka taka nie może być dedykowana je-

jest bieżace i nieprzerwane zaspokajanie zbiorowych potrzeb ludności w drodze świadczenia ustug powszechnie dostępnych.

30 Art. 61. 1. Wójt, burmistrz lub prezydent miasta może zlecić podmiotom, o których mowa $w$ art. 8 ust. 1, organizację opieki sprawowanej $w$ formie żłobka lub klubu dziecięcego lub przez dziennych opiekunów.

2. Do wyłaniania podmiotów mających organizować opiekę, o której mowa w ust. 1, stosuje się odpowiednio przepisy ustawy z dnia 24 kwietnia 2003 r. o działalności pożytku publicznego i o wolontariacie.

31 S. Gajewski [w:] S. Gajewski, A. Jakubowski, Ustawa o opiece, op. cit. Autor ten wskazuje również, że: Artykuł 61 ust. 2 ustawy odsyła w zakresie wyłaniania podmiotów mających organizować opiekę do przepisów ustawy o działalności pożytku publicznego i o wolontariacie. Oznacza to $w$ szczególności, że zastosowanie przy wyborze tych podmiotów znajda: art. 11 ust. 2-5 u.d.p.p.w. (obsługa konkursu) [ustawa z 24 kwietnia 2003 r. o działalności pożytku publicznego i wolontariacie - dopisek I.G.-R.], możliwość złożenia wniosku o realizację zadania publicznego (art. 12 u.d.p.p.w.), ogłoszenia konkursu ofert (art. 13 u.d.p.p.w.), treści oferty składanej do konkursu (art. 14 u.d.p.p.w.) i zasad jego rozstrzygania (art. 15 u.d.p.p.w.). Zlecenie zadania do realizacji następuje przez jego powierzenie wraz $z$ udzieleniem dotacji na jego finansowanie $w$ całości lub w części. Czynności te następują na podstawie umowy zawartej między gmina a podmiotem wyłonionym $w$ konkursie. Ze względu na fakt, że przepisy ustawy nie określają trybu ani zasad udzielania i rozliczania dotacji, a brakuje możliwości zastosowania w tym zakresie ustawy o działalności pożytku publicznego i o wolontariacie, treść zawartej umowy powinna odpowiadać regulacjom zawartym w art. 250 u.f.p. (zob. P. Światek, „Organizacja i finansowanie przez gminy...”, s. 8) [P. Świątek, Organizacja i finansowanie przez gminy zadań z zakresu opieki nad dziećmi w wieku do lat 3, „Finanse Komunalne" 2012, nr 7-8 - dopisek I.G.-R.]). 
dynie pracownikom określonej instytucji, ponieważ byłoby to sprzeczne z wyżej wskazanymi zasadami wykonywania zadań własnych przez gminę ${ }^{32}$.

Reasumując, należy stwierdzić, że z uwagi na fakt, iż zakładanie i utrzymanie żłobków należy do zadań własnych gminy (zarówno w zakresie utworzenia żłobka będącego gminną jednostką budżetową, jak i zlecenia utworzenia takiej placówki przez inny podmiot na podstawie art. 61 ust. 1 ustawy o opiece nad dziećmi w wieku do lat 3), czyli ma służyć zaspokajaniu potrzeb wspólnoty gminnej, nie wydaje się możliwe, by m.st. Warszawa mogło utworzyć złłobek, który nie byłby placówką ogólnodostępną, zwłaszcza że od 1 stycznia 2018 r. rozszerzono katalog podmiotów, które mogą utworzyć żłobki przyzakładowe, wskazując, że żłobki mogą zakładać i prowadzić m.in. instytucje publiczne (czyli m.in. Kancelaria Sejmu).

\section{Podsumowanie}

- Obowiązujące prawo pozwala na utworzenie przez Kancelarię Sejmu przyzakładowego żłobka. Placówka taka mogłaby funkcjonować jako zakładowy obiekt socjalny w rozumieniu ustawy o zakładowym funduszu świadczeń socjalnych.

- Kancelaria Sejmu nie jest uprawniona do utworzenia przedszkola, ponieważ nie może być zaliczana do podmiotów, które zgodnie z ustawą - Prawo oświatowe mogą tworzyć i prowadzić takie placówki.

32 C. Banasiński, K.M. Jaroszyński w komentarzu do art. 1 ustawy o gospodarce komunalnej ([w:] Ustawa o gospodarce komunalnej. Komentarz, 2017, LEX), prezentują następujące stanowisko: Spotykany jest pogląd, że zakresem podmiotowym pojęcia "gospodarka komunalna" objęta została także działalność odrębnych od jednostki samorzadu terytorialnego osób fizycznych, osób prawnych i jednostek organizacyjnych, którym samorząd powierzył wykonywanie zadań na podstawie umowy, o czym mowa wart. 3 u.g.k. [ustawa z 20 grudnia 1996 r. o gospodarce komunalnej - dopisek I.G.-R.]. Gospodarka komunalnq nie jest natomiast działalność podmiotów niedziałających na podstawie tego typu umowy, a obecnych na rynku usług, o których mowa (M. Szydło, Ustawa o gospodarce komunalnej. Komentarz, Warszawa 2008, s. 29-30). Oznacza to, że gospodarka komunalna obejmuje - z punktu widzenia podmiotowego - aktywność trzech kategorii podmiotów. Po pierwsze, wykonywanie zadań własnych przez gminy, powiaty $i$ województwa, a także przez tworzone przez jednostki samorządu terytorialnego inne jednostki organizacyjne. Po drugie, pojęcie gospodarki komunalnej odnieść należy do działalności związków jednostek samorządu terytorialnego, czyli związków międzygminnych (art. 64-73a u.s.g.) oraz związków powiatów (art. 65-72 u.s.p.) [ustawa z o samorządzie powiatowym - dopisek I.G.-R.]. Po trzecie, zakresem podmiotowym pojęcia "gospodarka komunalna” należy objąć także działalność podmiotów, innych niż powyższe, którym jednostki samorzadu terytorialnego powierzaja $w$ drodze umowy wykonywanie zadań z zakresu gospodarki komunalnej (art. 3 u.g.k.); C. Banasiński (w:) Prawo gospodarcze. Zagadnienia administracyjnoprawne, wyd. 4, red. M. Wierzbowski, H. Gronkiewicz-Waltz, Warszawa 2015, s. 12). 
- Według wstępnych danych z ogólnopolskiego rejestru żłobków prowadzonego przez Ministerstwo Rodziny, Pracy i Polityki Społecznej do końca 2018 r. nie powstał żłobek, którego założycielem jest urząd (instytucja publiczna).

- W Norwegii rodzice będący parlamentarzystami mogą korzystać odpłatnie z prywatnego przedszkola, do którego nabór jest uregulowany wytycznymi przyjętymi przez prezydium Stortingu.

- Obowiązujące regulacje nie pozwalają na utworzenie placówki, która stanowiłaby połączenie żłobka z przedszkolem.

- M.st. Warszawa może prowadzić jedynie przedszkola publiczne. Utworzenie przez tę jednostkę samorządu terytorialnego placówki, która miałaby charakter niepubliczny (przeznaczonej wyłącznie dla dzieci parlamentarzystów i pracowników Kancelarii Sejmu), nie jest możliwe.

- Z uwagi na fakt, że zakładanie i utrzymanie żłobków należy do zakresu zadań własnych gminy (zarówno w zakresie utworzenia żłobka będącego gminną jednostką budżetową, jak i zlecenia utworzenia takiej placówki przez inny podmiot na podstawie art. 61 ust. 1 ustawy żłobkowej), czyli ma służyć zaspokajaniu potrzeb wspólnoty gminnej, nie wydaje się możliwe, by m.st. Warszawa mogło utworzyć żłobek, który nie byłby placówką ogólnodostępną, zwłaszcza że od 1 stycznia 2018 r. rozszerzono katalog podmiotów, które mogą utworzyć żłobki przyzakładowe (wskazując, że żłobki mogą zakładać i prowadzić m.in. instytucje publiczne).

\section{Bibliografia}

Banasiński C. [w:] Prawo gospodarcze. Zagadnienia administracyjnoprawne, red. M. Wierzbowski, H. Gronkiewicz-Waltz, Warszawa 2015.

Banasiński C., Jaroszyński K.M., Komentarz do art. 1 [w:] Ustawa o gospodarce komunalnej. Komentarz, 2017, LEX.

Gajewski S. [w:] S. Gajewski, A. Jakubowski, Ustawa o opiece nad dziećmi w wieku do lat 3. Komentarz, 2014, LEX.

Martuszewicz A., Piecyk K., Ustawa o zakładowym funduszu świadczeń socjalnych. Komentarz, 2011, LEX.

Niedziński T., Zakładowy Fundusz Świadczeń Socjalnych. Komentarz, 2011, Legalis.

Szydło M., Ustawa o gospodarce komunalnej. Komentarz, Warszawa 2008.

Szpringer Z., Informacja na temat finansowania działalności poselskiej w Norwegii, „Studia BAS” 2007 [Świadczenia poselskie w różnych krajach, red. Z. Szpringer].

Świątek P., Organizacja i finansowanie przez gminy zadań z zakresu opieki nad dziećmi $w$ wieku do lat 3, „Finanse Komunalne” 2012, nr 7-8.

Uziębło P. [w:] K. Grajewski, J. Stelina, P. Uziębło, Komentarz do ustawy o wykonywaniu mandatu posła i senatora, Warszawa 2014.

Wierzbica A., Miasto na prawach powiatu. Zagadnienia ustrojowe, Warszawa 2006. 